\title{
Some insights on physical education classes in primary and secondary schools in Bihor County, Romania
}

Authors' Contribution: A Study Design

B Data Collection

C Statistical Analysis

D Data Interpretation

E Manuscript Preparation

F Literature Search

G Funds Collection

\author{
Claudia Georgescu ${ }^{1}$ ABCDEF, Roxana (Tătar) Firezar ${ }^{2}$ ABCDEF, Petru Pețan ${ }^{3 \text { ABCDEF }}$ \\ ${ }^{1}$ School and University Sports Federation, Romania \\ 2 Ph.D. candidate, Faculty of Geography, Tourism and Sport, University of Oradea, Romania \\ ${ }^{3}$ Faculty of Geography, Tourism and Sport, University of Oradea, Romania
}

\section{abstract}

Background: The paper presents some insights into the organisation of physical education classes in primary and secondary (lower secondary level) schools in Bihor county, Romania.

Material and methods: The analyses are descriptive and address sports games played in physical education classes, time allotted to these classes, and also the quality of present sports infrastructure in schools. Data were collected by questionnaires applied to physical education teachers from primary and secondary schools in rural and urban areas, which were then descriptively analysed.

Results: The results indicate an insufficient number of physical education hours established in the primary and secondary school curriculum. Conclusions. There is a need to improve the quality of sports infrastructure and facilities in schools (synthetic sports fields, multisport fields, etc.), both through the involvement of school management and local public authorities.

Conclusions: There is a need to improve the quality of sports infrastructure and facilities in schools (synthetic sports fields, multisport fields, etc.), both through the involvement of school management and local public authorities.

Key words: physical education classes, primary and secondary schools, sports games, sports infrastructure, physical education teachers.

\section{article details}

Article statistics: Word count: 2,745; Tables: 0; Figures: 7; References: 36

Received: June 2020; Accepted: August 2020; Published: November 2020

Full-text PDF: http://www.balticsportscience.com

Copyright @ Gdansk University of Physical Education and Sport, Poland

Indexation: Celdes, Clarivate Analytics Emerging Sources Citation Index (ESCI), CNKI Scholar (China National Knowledge Infrastructure), CNPIEC, De Gruyter - IBR (International Bibliography of Reviews of Scholarly Literature in the Humanities and Social Sciences), De Gruyter - IBZ (International Bibliography of Periodical Literature in the Humanities and Social Sciences), DOAJ, EBSCO - Central \& Eastern European Academic Source, EBSCO - SPORTDiscus, EBSCO Discovery Service, Google Scholar, Index Copernicus, J-Gate, Naviga (Softweco, Primo Central (ExLibris), ProQuest - Family Health, ProQuest - Health \& Medical Complete, ProQuest - Illustrata: Health Sciences, ProQuest - Nursing \& Allied Health Source, Summon (Serials Solutions/ProQuest, TDOne (TDNet), Ulrich's Periodicals Directory/ulrichsweb, WorldCat (OCLC)

Funding: This research received no specific grant from any funding agency in the public, commercial, or not-for-profit sectors.

Conflict of interests:

Authors have declared that no competing interest exists.

Petru Pețan, Universitatii street, no. 1, Oradea, Romania. Phone: +40 746101846 E-mail: petanp1967@yahoo.com This is an open access article distributed under the terms of the Creative Commons Attribution-Non-Commercial-NoDerivatives 4.0 International (https://creativecommons.org/licenses/by-nc-nd/4.0/), which permits use, distribution and reproduction in any medium, provided the original work is properly cited, the use is non-commercial and is otherwise in compliance with the license. 


\section{INTRODUCTION}

Promoting a healthy lifestyle must be the main goal of both physical education and sports. However, very little is known about the relationship between different lifestyles and patterns of physical activity among young people [1-3]. Physical activity and sports can improve health, develop a healthy lifestyle, establish and maintain social relationships [46]. These aspects must be addressed by the content of physical education classes[7]. Lack of physical activity can negatively contribute to health, favouring the occurrence of certain diseases (diabetes, obesity etc.). In this context, certain strategies must be established by competent institutions as well as through school syllabus in order to promote a healthy lifestyle and ensure an optimal mental and physical status [8-10]. Physical activity is a determinant factor of physical and mental health. Regular physical activity has benefits on individual's wellbeing and positively influences social relationships. Physical activity can also be an active way of spending free time [11, 12]. Unfortunately, more than $60 \%$ of adults worldwide do not attain recommended levels of physical activity [13-15].

The paper addresses an important topic at both community and society level: the schedule of physical education classes in the pre-university curriculum in Romania [16]. The importance of investigating this topic stems from the need to ensure the highest possible level of health among students [17]. In formal education, sport, developed through optimal physical education classes, reduces sedentary lifestyle and increases students' physical wellbeing [18]. The present paper considers a brief analysis of the literature on the formal organisation of physical education classes at pre-university level in Romania, detailing aspects such as the optimal number of hours dedicated to physical education in the school curriculum, or primarily sports games played during these classes. Also, special attention is paid to the need for quality sports infrastructure in schools, especially the need for synthetic or multisport sports fields and gyms for physical activities [19, 20]. Furthermore, the methodological framework of the research is presented, followed by a brief presentation of socio-demographic characteristics of respondents. Data are subsequently analysed, and research results are presented and discussed. Eventually, the main conclusions of the study are summarised.

\section{LEGISLATIVE ASPECTS OF PHYSICAL EDUCATION AND SPORTS IN PRIMARY AND SECONDARY SCHOOLS IN ROMANIA}

The content of physical education classes, the way in which they influence the health status of primary and secondary school students is a problem faced by many countries in the European Union, including Romania [21, 22]. Researchers state that this level lays the foundation for lifelong physical activity, as well as more complex future activities, such as sports [23-28]. Also, physical education classes as well as a balance of time allotted must ensure the continuity of physical activities from primary to secondary school [29]. Physical education and sports in primary and secondary schools in Romania is regulated by the National Education Law no. 1/2011 [30] and is based on a school curriculum approved by the Order of the Ministry of Education no. 4686/05.08.2003 (Annex 5) for grades I-II [31] as well as by the Order of the Ministry of Education 5003/02.12.2014 (Annex 2), regarding the approval of school curricula for primary education, grades IIIIV [32]. According to these regulations, a number of objectives must be pursued at the primary level (grades I to IV):

- maintaining students' optimal health and increasing their ability to adapt to environmental factors,

- harmonising one's own physical development and preventing possible deviations,

- acquiring basic motor, applicative-utilitarian and sports skills,

- practising physical exercises and of different games and sports independently,

- manifesting the team and competition spirit based on a system of accepted rules,

- using specialised language for the development of physical activities and sports, 
- optimising the health state through physical activity as a result of a better function of the main body parts and systems (respiratory, circulatory, digestive systems, etc.), as well as of a better muscular dynamics,

- adopting an appropriate behaviour in interpersonal and group relationships, based on respect and fair-play in physical activities developed in and out of educational context.

At the lower secondary level, physical education and sports are regulated by the Order of the Ministry of Education no. 5097/09.09.2007 (Annex 5) [33]. According to these regulations, the following objectives must be pursued at the lower secondary level (grades V-VIII):

- practising physical education and sport to generate benefits for the health level which constitutes the base for an efficient practice of physical activity,

- using benefits generated by physical education and sports for motor skills and harmonious physical development,

- adopting an adequate behaviour by following specific rules during the organisation, practice and participation as a spectator in physical education and sports activities.

According to school curricula and the before-mentioned normative acts, at the primary and secondary level, 2 hours of physical education are allocated per week. In addition to achieving the aimed objectives, the structure of physical education classes also includes sports activities meant to stimulate students' interest in competition and implicitly in sports. Romanian authorities tend to minimise the importance and the role of physical education, a fact proved by Order no. 3309/02.03.2009, which limits the number of physical education hours to only one per week [34]. These regulations are in contradiction with the provisions and recommendations of the European Union. In fact, the European Union declared the year 2004 officially as the "European Year of Education through Sport". Therefore, the European Commission encourages the support of physical and sports activities through policy initiatives at the level of each member state. The best example in this regard is the European Parliament's resolution of 13 November 2007 on the role of sport in education (2007/2086) [35], which, among others:

- calls on member states to foresee a compulsory character to physical education in schools and high schools and to accept principles according to which at least three hours of physical education should be scheduled weekly, and schools should be encouraged to exceed this threshold depending on their possibilities;

- encourages member states to modernise and improve their physical education policies by ensuring, in particular, a balance between physical and intellectual activities in schools, to invest in sports facilities in schools and training centres, and to take necessary measures to render sports facilities and school curriculum accessible to all students, paying due attention to those with disabilities; suggests the support for a wide range of sports activities, so that all students have a real chance to practice different sports; calls on member states to agree on the need to increase the number of physical education hours in schools; calls on member states to promote the recognition of institutions and organisations that contribute to a better integration of sports activities in the educational system; agrees to financial benefits for sports clubs that have collaboration agreements with schools, educational institutions, youth centres and other voluntary or community organisations involved in lifelong learning projects;

- calls on member states to ensure adequate conditions for compliance with minimum number of physical education hours, given that constant physical activity significantly reduces health care expenditures.

Based on these regulations, one can observe the importance given by European Union bodies to the number of physical education hours, and also to the quality and calibration of sports infrastructure to students' educational and performance needs. Research outlines that sport infrastructure implies both physical and human aspects [36]. 


\section{MATERIAL AND METHODS}

Research objectives. The general research objective was outlined based on the study topic: describing the organisation of physical education classes at primary and secondary schools in Bihor county, Romania. In this regard, we were interested in the perspective of physical education teachers. Based on the general objective, the following specific research objectives were outlined:

SO1. Identifying the optimal number of physical education classes at primary and secondary school level

SO2. Identifying the sports games played primarily during physical education classes in schools from Bihor county, Romania

SO3. Identifying the quality of sports infrastructure in schools from Bihor county, Romania

Research method and data collection tool. Our research uses a quantitative strategy, and data were directly collected from respondents. The research tool used to collect the data was the questionnaire. It included several questions regarding the organisation and development of physical education classes in rural and urban schools from Bihor county. Data were collected between September-December 2019.

The subjects were physical education teachers, specialised in various sports disciplines, from the primary and secondary level in urban and rural schools in Bihor county. The total number of respondents was 227.

\section{SOCIO-DEMOGRAPHIC CHARACTERISTICS OF THE RESPONDENTS}

Gender. Our respondents were mainly male (76.4\%). This disparity of gender distribution between respondents may be due to activity specifics: they are physical education teachers, a professional activity more biased towards men.

Age. The respondents were aged between 22 and 65 years old, with the mean age being 38.7 years.

Teacher certification level. Most respondents (45.8\%) had the teacher certification degree 1 , while $21.6 \%$ had the teacher certification degree 2 , and the same percentage was registered in the case of respondents with permanent teaching certificate. Only $1.3 \%$ had obtained a PhD diploma (Figure 1). Results indicate the interest of physical education teachers in achieving high degrees of teaching certification, especially level 1; also, some of them aim to obtain a PhD diploma in their field of specialisation. The higher teaching certification degree, the higher incomes for pre-university teachers. The tendency to obtain higher degrees of teaching certification as soon as possible is suggested also if we consider the average age of our respondents (38.7 years), as well as the average value of their professional experience in education: 13.36 years.

The majority of our respondents (75.8\%) hold their teaching positions for a non-determined period of time. This security of their jobs provides them with an opportunity to be more involved in their educational activity. $84.7 \%$ of our respondents teach at primary schools, while only $15.3 \%$ develop their professional activity at the lower secondary level (Figure 2). However, it is worth mentioning that lower secondary educational level is less present in schools from rural areas in Romania.

Physical Education graduates obtain a specialisation in a certain sport disciplines. Data show that the majority of respondents (62.5\%) specialise in four types of sports (football, handball, basketball, volleyball), while $37.5 \%$ of them have another sports specialisation (Figure 3). 


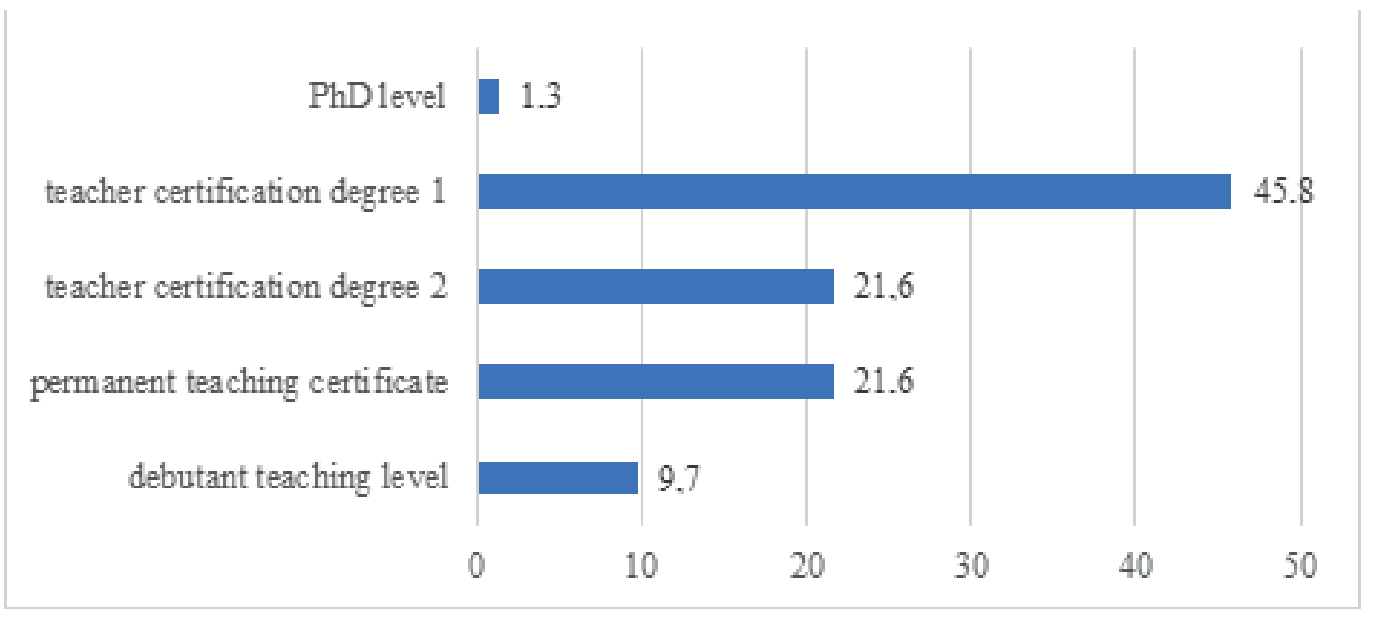

Fig. 1. Respondents' teaching certification degree (\%)

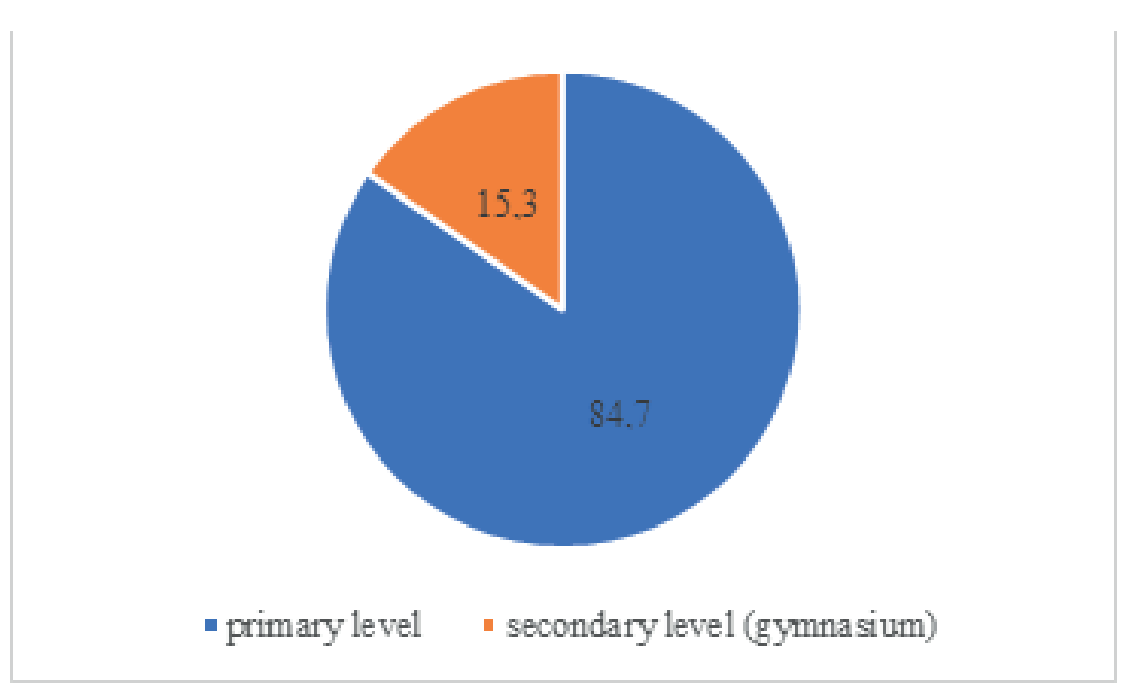

Fig. 2. Educational level where the respondents teach (\%)

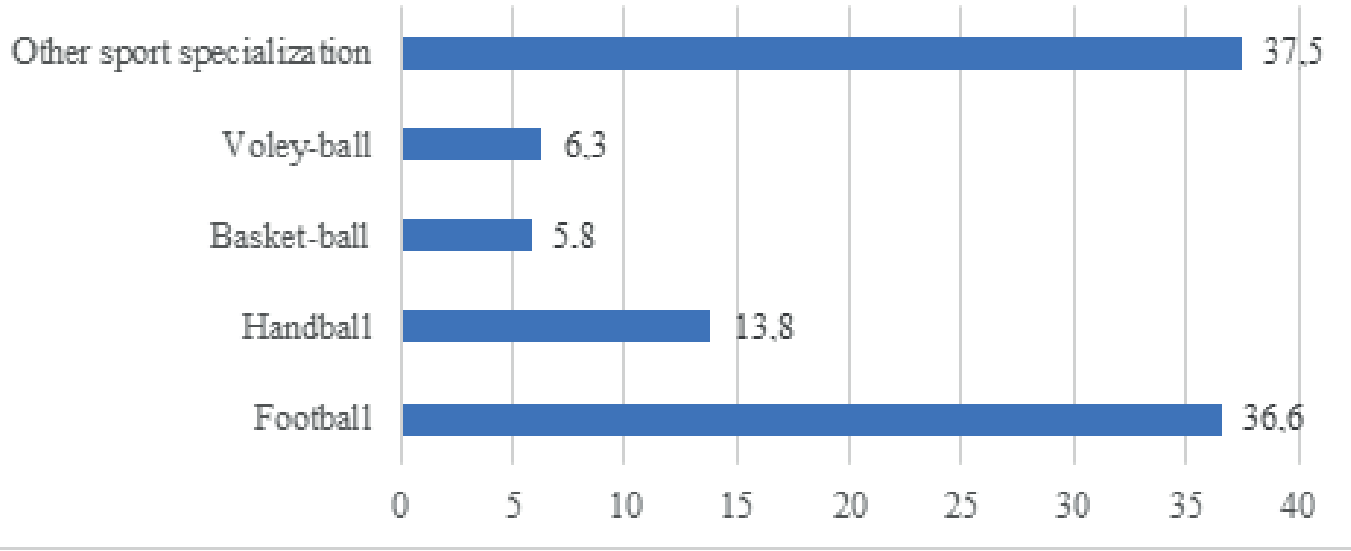

Fig. 3. Respondents' professional specialisation (\%)

This distribution of various sports disciplines (36.6\% - football, 13.8\% - handball, $6.3 \%$, volleyball, $5.8 \%$ - basketball) overlaps with the hierarchy of the most played sport games in Romanian schools. This aspect is closely determined by the sports infrastructure in schools: all schools have a delimited area for football or handball, and very few have the necessary facilities for playing volleyball or basketball. 


\section{RESULTS AND DISCUSSION}

\section{Physical education CLASSES IN SCHOOLS}

Results show that $50.7 \%$ of schools are located in urban areas and $48.5 \%$ are rural schools. This highlights a relatively uniform distribution of schools in Bihor county, which indicates a concern of local authorities (City Halls and County Councils) to ensure equal educational conditions both for urban and rural areas.

$86.7 \%$ of the respondents consider that the number of hours allotted to playing different sport games during physical education classes in schools is not enough (Figure 4). According to the school curriculum, the number of physical education hours at primary and secondary levels does not exceed 2 hours per week. This number of physical education hours is not enough. Our research results show that the average number of necessary hours would be 3.69/week. This number is also close to the recommendations made by the European Union regulations. It is noticed the need to increase the number of physical education hours in Romania in order to achieve the proposed educational objectives.

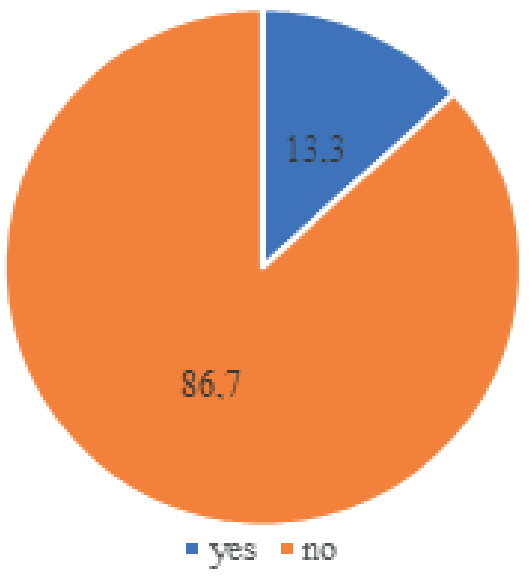

Fig. 4. Time allotted to playing sport games during physical education classes (\%)

Football, basketball, handball, volleyball are the most played sports games during physical education classes in schools from Bihor county. This distribution complies with the beforementioned hierarchy of sports specialisations in the case of physical education teachers. In addition to these sports games (the practice of which is also conditioned by the sport infrastructure in schools), also sports such as rugby-tag, oina (a typical Romanian sports game) or table tennis are mentioned, even if with a lower frequency. In order to be practiced in schools, football and handball do not require infrastructure that is difficult to obtain. Our study also aimed to find out if physical education teachers at primary and secondary levels are satisfied with the current sports infrastructure in schools and if they consider that also other sports games can be played in decent conditions in schools.

Regarding the sports infrastructure in schools, the highest percentages are registered in the case of subjects who evaluate its quality as acceptable (32\%) and rather good (40\%). Subjects who appreciate the quality of sports infrastructure in schools as poor and very poor is clearly lower than those who appreciate it as acceptable, good and very good (Figure 5). This aspect is surprising and, at the same time, gratifying because this means that physical education teachers can carry out their activity in good conditions. 


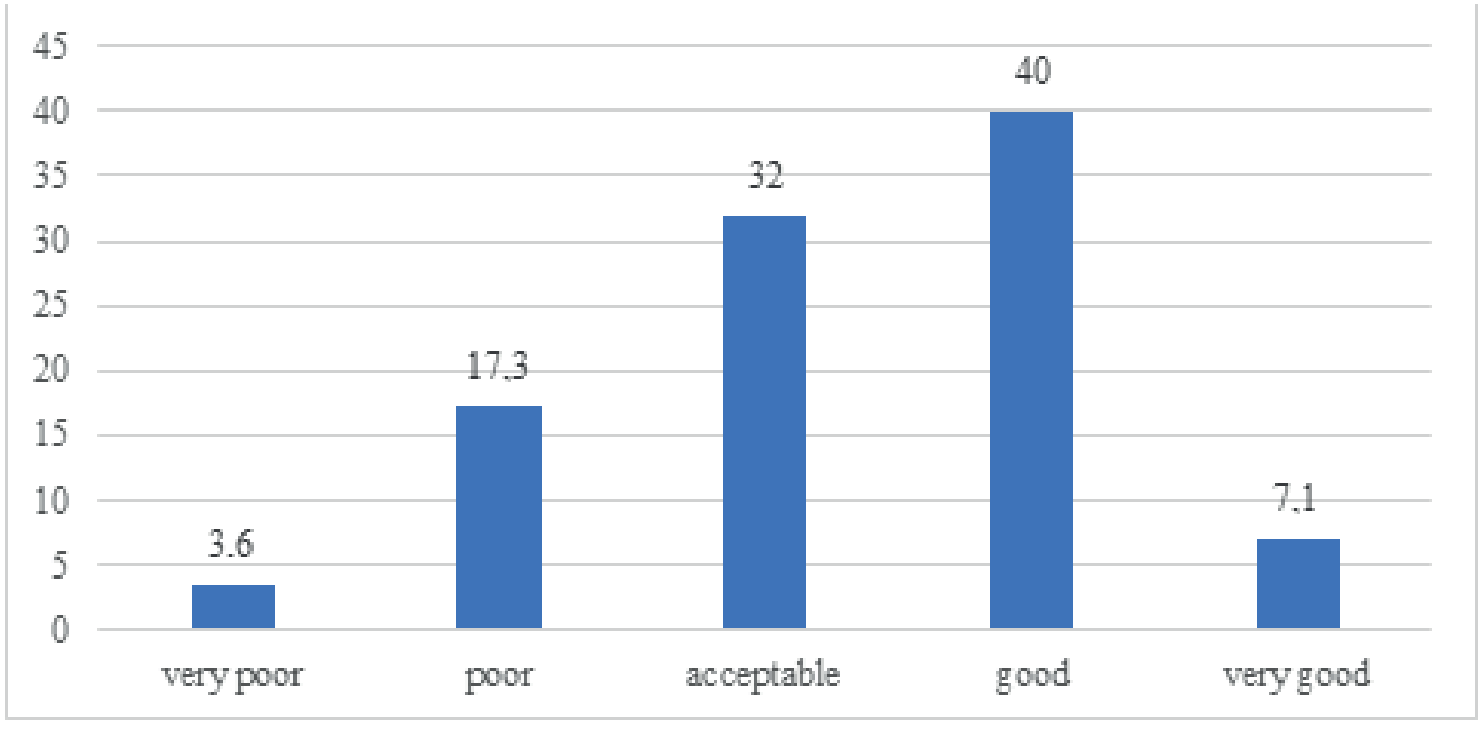

Fig. 5. The quality of sports infrastructure in schools (\%)

Regarding the quality of sports infrastructure, especially regarding artificial sports turfs or multisport floorings, respondents provided surprising answers. More than half of them (54.5\% of respondents) declared that there were no synthetic or multisport floorings in their schools. However, $45.6 \%$ of them stated that they had such a sport facility in the school where they taught (Figure 6). This aspect can motivate physical education teachers to develop more physical and also extracurricular activities. The sport facilities provided by schools to physical education teachers represent a permanent issue for them. The increase in the quality of sports infrastructure is a constant requirement coming from teachers, but this is also a condition in order to increase the quality of physical education classes and to motivate students to get more involved in these educational activities.

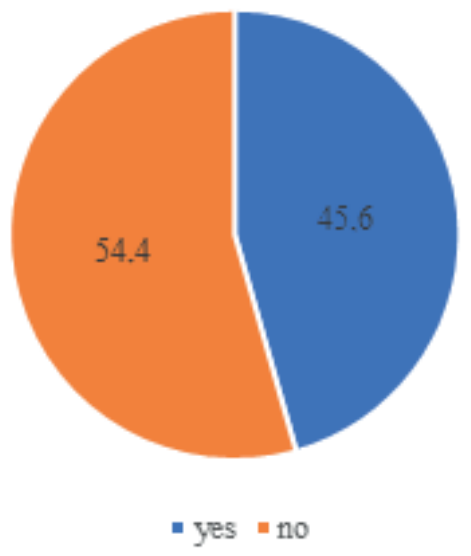

Fig. 6. Artificial sports turf and multisport flooring in schools (\%)

The majority of the respondents (82.4\%) considered the City Hall to be the one that should contribute the most to the improvement of sports infrastructure at school level, followed by subjects (52.4\%) who considered that the management staff of each school should be more involved in this regard. The private business sector as well as students' parents were not perceived as having an obligation to intervene in this regard (Figure 7). 


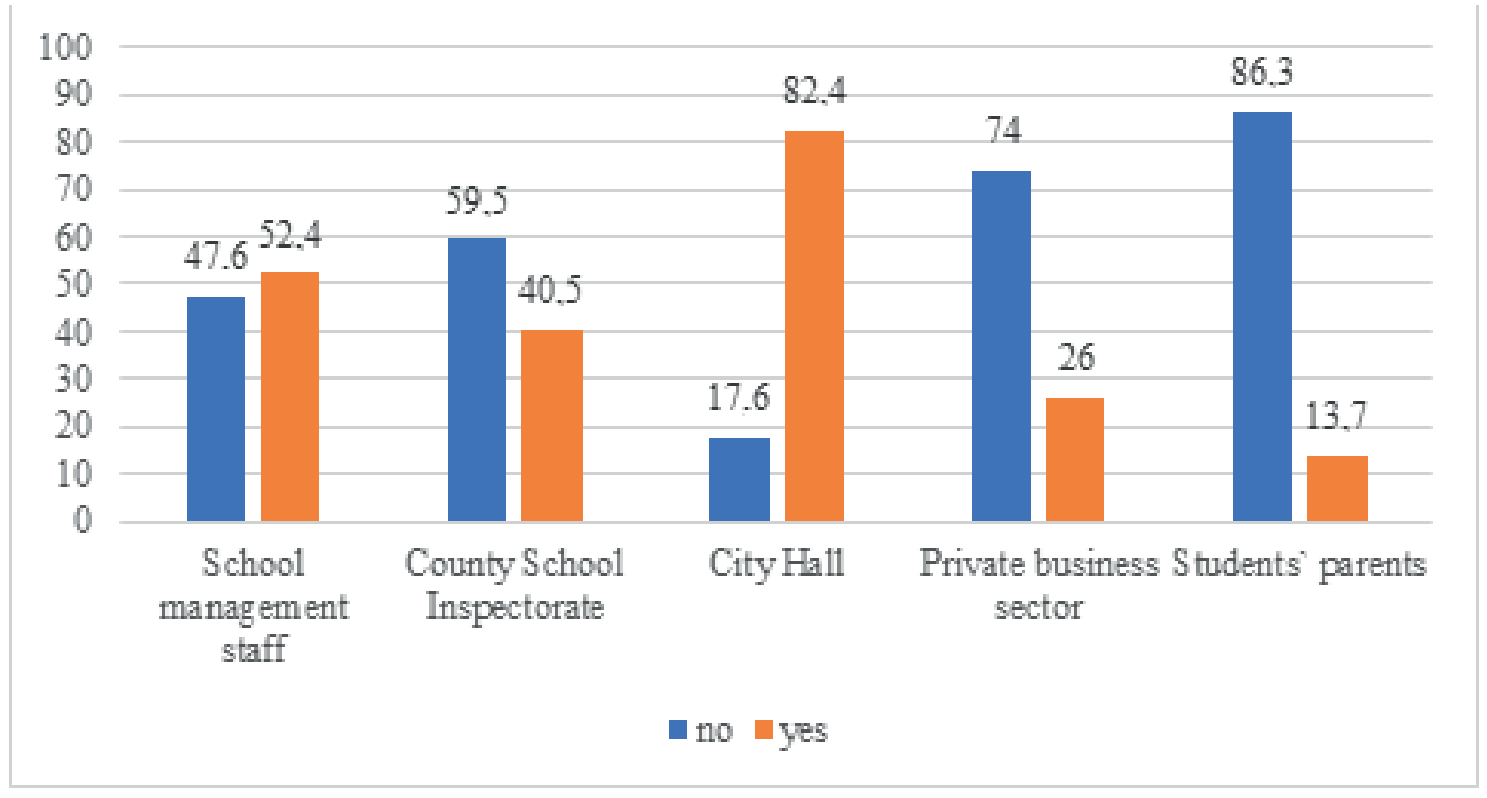

Fig. 7. Contribution to improve sports infrastructure in schools (\%)

Research limitation. Our study provided a descriptive analysis in what regards physical education classes at primary and secondary (lower secondary) levels in schools from Bihor county, Romania. Therefore, one of the methodological research limitations is outlined: high schools are not included in our investigation. This could represent a future research direction.

\section{CONCLUSIONS}

Our research results indicate that 2 hours of physical education classes per week, scheduled by the school curriculum, are not enough. This number should be increased at primary and secondary school levels and should reach 3-4 hours weekly. In fact, these are also European Union recommendations in order to respect students' rights to education, to a modern sports infrastructure and their access to sports events and manifestations. Also, the most played sports games during physical education classes are football, basketball, volleyball and handball. This aspect is conditioned by several factors: they are the most frequent sports specialisations provided by higher education institutions in Romania, these sports games have the highest public appeal (also among children), and the facilities and infrastructure necessary for their development is not very difficult to achieve at minimum conditions. However, we note that a high percentage of respondents state that they have access to a high quality sports infrastructure in schools where they teach. But there is still a high number of schools in Bihor county (and the situation could be extended at national level) which do not have such sport facilities (with emphasis on artificial sport turfs or multisport floorings) in order to develop physical education classes in decent conditions.

A greater involvement of the local authorities, especially of City Halls, but also of the school management is required for an optimal development of these classes. They must intervene and find necessary resources to improve sport facilities for physical activities, which can thereby contribute to an increased level of health and wellbeing among students. 


\section{REFERENCES}

[1] Ilies DC, Buhas R, Ilies M, et al. Sport activities and leisure in Natura 2000 protected area - Red Valley, Romania. J Environ Protect Ecology. 2018a;19(1):367-372.

[2] Kostecka K, Bojanowska M, Stoma M. The role of physical activity in instilling healthy lifestyle habits children. Balt J Health Phys Activ. 2017;9(3):133-140. https://doi.org/10.29359/BJHPA.09.3.13

[3] Szczepanska-Klunder Z, Lipowski M. The role of self - efficacy in undertaking health - seeking behaviours by physical education teachers. Balt J Health Phys Activ. 2015;7(2):45-57.

[4] Dragos P, Lucaciu G, Dinis I, Stef Gavris M, Szabo-Alexi P, Buhas S. Concepts concerning the content of children's training in some sport games Proceedings of the 4th international conference of the universitaria consortium (ICU 2018): The impact of sport and physical education science on today society, 62 - 72. Editografica SRL, INTL Proceedings Div, Bologna, Italy. 2018a.

[5] Scutti G, Wendt JA. Football and Geopolitics. GeoSport for Society. 2016;5(2):100-106.

[6] Buhas S. Sport and Physical Education - Forms of Socialization. GeoSport of Society. 2015;3(2):53-60.

[7] Telama R, Nupponen H, Pieron, M. Physical activity among young people in the context of lifestyle. European physical education review. 2005;11(2):115-137. https://doi.org/10.1177/1356336X05052892

[8] Gaetano A. Relationship between physical inactivity and effects on individual health status. Journal of physical education and sports. 2016;16(2):1069-1074. https://doi.org/10.7752/jpes.2016.s2170

[9] Marcu V, Buhas S. Sport Organizations - management and science. Procedia-Social and Behavioral Sciences. 2014;117:678-682. https://doi.org/10.1016/j.sbspro.2014.02.281

[10] Dragos P, Lucaciu G, Trifa I, Stef Gavris M, Szabo - Alexi P, Buhas S. Aspects regarding the influence of communication on the motivation of employees in some sports organisations. Proceedings of the 4 th international conference of the universitaria consortium (ICU 2018): The impact of sport and physical education science on today society, 73 - 77. Editografica SRL. INTL Proceedings Div. Bologna, Italy. 2018b.

[11] Ratkowski W, Lapian T. Recreational Offer On The Example Of Sopot, GeoJournal of Tourism and Geosites. 2010;6(2):174-183. [Available at http://gtg.webhost.uoradea.ro/PDF/GTG-2-2010/07 GTG-57-Ratkowski+Lapjan. pdf]. [Accessed on 3 May 2020].

[12] Ratkowski W, Lapian T, Szumilewicz A. Sport-recreational infrastructure of Sopot. GeoJournal of Tourism \& Geosites. 2011;7(1):115-131. [Available at http://gtg.webhost.uoradea.ro/PDF/GTG-1-2011/11_71_Ratkowski+.pdf]. [Accessed on 3 May 2020].

[13] Kruk J. Physical activity and health. Asi Pacific J Cancer Prevent. 2009;10:721-728.

[14] Wang G, Pratt M, Macera CA, Zheng ZJ, Heath G. Physical activity, cardiovascular disease, and medical expenditures in U.S. adults. Ann Behav Med. 2004;28:88-94. https://doi.org/10.1207/s15324796abm2802_3

[15] Yancey AK, Fielding JE, Flores GR. Creating a robust public health infrastructure for physical activity promotion. Am J Prev Med. 2007;32:68-78. https://doi.org/10.1016/j.amepre.2006.08.029

[16] Hantiu I, Stanescu M. Particularities of school physical education in Romania. Palestrica of the Third Millennium Civilization and Sport. 2011;12(3):258 - 264.

[17] Pop CL. Physical and health education for a resilient future workforce. Rom J Multidimens Educ. 2015;7(2):133-140. https://doi.org/10.18662/rrem/2015.0702.12

[18] Soos I, Biddle S, Boros-Balint I, et al. Prevalence of sedentary behaviour in young people in Romania and Slovakia. Eur Phys Educ Rev. 2012;18(1):19-46. https://doi.org/10.1177/1356336X11430659

[19] Onet A, Ilies DC, Buhas S, et al. Microbial Air Contamination in Indoor Environment of University Sports Hall. J Environ Protect Ecology. 2018;19(2):694-703.

[20] Ilies DC, Buhas R, Ilies A, et al. Indoor Air Quality Issues. Case Study: The Multipurpose Sports Hall of the University of Oradea. Environ Eng Management J. 2018b;17(12):2999-3005. https://doi.org/10.30638/eemj.2018.300

[21] Ilies A, Dehoorne O, Wendt JA, Kozma G. For Geography and Sport, Sport Geography or Geography of Sport. GeoSport for Society. 2014;1(1-2):7-18.

[22] Derlaga A, Wendt J. Cross-border co-operation between the Republic of Romania, Ukraine and Moldova. In: Kitowski $\mathrm{J}$, editor. Regional transborder co-operation in countries of Central and Eastern Europe - a balance of achievements. Warsaw: PAN, Geopolitical Studies; 2004; 14, 141-158.

[23] Griggs G. Physical education: primary matters, secondary importance. Int J Prim Element Early Years Educ. 2007;35:59-69. https://doi.org/10.1080/03004270601103350

[24] Randall V. Becoming a primary physical educator. Education. 2020;48(2):133-146. https://doi.org/10.1080/030042 79.2019.1594330

[25] Duncombe R, Cale L, Harris J. Strengthening 'the foundations' of the primary school curriculum. Education. 2018;46(1):76-88. https://doi.org/10.1080/03004279.2016.1185137

[26] Jess M, McEvilly N, Carse N. Moving primary physical education forward: start at the beginning. Education. 2017;45(5):645-657. https://doi.org/10.1080/03004279.2016.1155072

[27] Dehoorne O, Wendt J. A, Mikhailov A, Berdenov Z, Ilies A. Cartographic representation of a sports (football) competition - UEFA Youth League (2013-2019). Geosport for Society. 201911(2):86-100. https://doi.org/10.30892/gss.1104-051

[28] Buhas S, Herman G, Stef-Gavris M. Aspect regarding speed development in football game in 12 - 14 years old children. GeoSport for Society. 2018;8(1):21 -29.

[29] Taylor MI, Spray MC, Pearson N. The influence of the physical education environment on children's well - being and physical activity across the transition from primary to secondary school. Human Kinetics Journals. 2014;36(6):574583. https://doi.org/10.1123/jsep.2014-0038

[30] Romanian Parliament. Legea Educatiei Nationale 1/2-2011 [National Education Law no. 1/2011] published in the Official Monitor no.18 from 10 January 2011. Romanian. [Available at https://www.edu.ro/sites/default/files/ fi\%C8\%99iere/Minister/2017/legislatie\%20MEN/Legea\%20nr.\%201 2011 actualizata2018.pdf]. [Accessed on 8 May 2020]. 
[31] Ministry of National Education and Scientific Research (Romania). Ordin nr. 4686/05.08.2003 privind aprobarea Planului-cadru de invatamant şi a programelor scolare pentru clasele I - a II-a, in conditiile inceperii invatamantului obligatoriu la varsta de 6 ani [Order no. 4686 / 05.08.2003 on the approval of the education framework plan and of the school curricula for I - II grades, in the context of compulsory education starting from the age of 6] (Annexe 5). Romanian. [Available at http://www2.edu.ro/index.php/articles/186]. [Accessed on 9 May 2020].

[32] Ministry of National Education and Scientific Research (Romania). Ordin nr. 5003/02.12.2014 privind aprobarea programelor scolare pentru invatamant primar, clasele a III-a si a IV-a (Annexe 2). [Order no. 5003 / 02.12 .2014 on the approval of school curricula for primary education, grades III and IV]. Romanian. [Available at http://oldsite.edu. ro/index.php/articles/22407]. [Accessed on 8 May 2020].

[33] Ministry of Education, Research and Innovation (Romania). Ordinul nr. 5097/2009 privind aprobarea programelor școlare pentru disciplinele de studiu din invatamantul preuniversitar secundar inferior, ciclul gimnazial [Order no. $5097 / 2009$ on the approval of school curricula for disciplines in lower secondary pre-university education, lower secondary]. (Annex 5). Romanian. [Available at https://lege5.ro/Gratuit/gezdsnbugq/ordinul-nr-5097-2009-privindaprobarea-programelor-scolare-pentru-disciplinele-de-studiu-din-invatamantul-preuniversitar-secundar-inferiorciclul-gimnazial]. [Accessed on 2 May 2020].

[34] Ministry of Education, Research and Innovation (Romania). Ordinul ministrului educatiei, cercetarii si inovarii nr. 3309/02.03.2009 cu privire la aprobarea planurilor-cadru de invatamant pentru clasa a IX-a, ciclul inferior al liceului, filiera tehnologica, invatamant de zi si invatamant seral [Order of the Minister of Education, Research and Innovation no. 3309 / 02.03.2009 regarding the approval of the educational framework plans for the ninth grade, the lower cycle of high school, the technological branch, day education and evening education]. Romanian.

[35] European Parliament resolution of 13 November 2007 on the role of sport in education (2007/2086). Romanian. [Available at https://op.europa.eu/en/publication-detail/-/publication/5c83e219-9f93-4104-9c42-b18f757a75ac/language-en]. [Accessed on 8 May 2020].

[36] Kozma G. Sport as an Element in the Place Branding Activities of the Local Government. GeoJournal of Tourism and Geosites. 2010;6(2):133-143. [Available at http://gtg.webhost.uoradea.ro/PDF/GTG-2-2010/03_GTG-64-Kozma.pdf]. [Accessed on 27 April 2020]. 